\title{
An Empirical Study Based on Supply Chain Supplier Evaluation System
}

\author{
Quan Qu' ${ }^{1}$ Lina Fang2 ${ }^{*}$ Yu Hou ${ }^{2}$ \\ ${ }^{1}$ Business Administration, Beijing Commerce \& Trade School, Beijing, China \\ ${ }^{2}$ Business Administration, University of Science and Technology Liaoning, Anshan, China \\ Email: yuanqu@sohu.com, *asfanglina@163.com
}

How to cite this paper: Qu, Q., Fang, L.N. and Hou, Y. (2016) An Empirical Study Based on Supply Chain Supplier Evaluation System. Journal of Service Science and Management, 9, 409-415.

http://dx.doi.org/10.4236/jssm.2016.95045

Received: June 6, 2016

Accepted: October 11, 2016

Published: October 14, 2016

Copyright $\odot 2016$ by authors and Scientific Research Publishing Inc. This work is licensed under the Creative Commons Attribution International License (CC BY 4.0)

http://creativecommons.org/licenses/by/4.0/

\begin{abstract}
Under the environment of supply chain, enterprises not only put forward higher request to the product itself, but also focus more on the supplier selection criteria. In the early stage of the supply chain construction enterprises, we will find that there are many outstanding suppliers to choose from; facing a large number of suppliers, an effective way of supplier evaluation is very important. In this paper, the principal component analysis method is applied in supplier evaluation index, by extracting the principal components of the multi index comprehensive evaluation, and quantitatively provides guidance and reference for the selection of suppliers for the enterprises in the supply chain.
\end{abstract}

\section{Keywords}

Supplier, Principal Component Analysis, Comprehensive Evaluation

\section{Introduction}

With the advent of the era of economic globalization, the management of modern enterprise has changed; the supply chain management mode has become more and more popular. Supply chain is composed of suppliers, manufacturers and distributors, in which the three suppliers in the main position are to enhance the efficiency of the supply chain, an important way to improve the operational efficiency of the supply chain. An ideal supplier will not only help enterprises to reduce production costs, and improve product quality, but also determine the supply chain to run the degree of stability and operational efficiency. Screening reasonable supplier has become a strategic weight to enhance the core competitiveness of enterprises. The principal component analysis is applied to the supplier evaluation system, and the principal component analysis method is applied to the evaluation of the supplier under the multi index sys- 
tem. The weight is determined by the variance contribution rate, which overcomes the defect of artificial weight. The weight contains the amount of information of the original data, so it is objective and reasonable.

\section{Relevant Literature Research Status}

In the current supply chain management, there are many suppliers of the evaluation criteria, which makes the companies have chosen to become more complex. HuangYao Guo believed that the four main indicators of quality, price, technical capability, and transmission reliability can be a better measure of supplier [1]. Bi-Bo Qian thought by AC (the opportunity to achieve the ability accomplishment), ad (the application of computer and information technology advancement advancement), I (innovation ability) and 1 (logistics), E (environment), M \& C (enterprise management level and cultural management \& Culture) and other factors as a supplier evaluation index can a full range of suppliers to understand, also contribute to the implementation of enterprise decision [2]. Xin'an Ma presented a theoretical framework for supplier selection based on existing theory, he believes corporate supplier selection process should be divided into suppliers of coarse screening, fine screening suppliers, vendors and confirm scouring evaluated four stages tracking suppliers, and finally also need to apply quantitative comprehensive evaluation method, the formation of a unified supplier evaluation criteria [3]. Moore and Fearon proposed product price, quality and delivery is a key indicator of vendor selection, and linear programming is proposed for this decision [4]. Johnson $\mathrm{M}$ using the excellent enterprise evaluation methods, field trips from Supplier's strategy, culture, processes and technology in four areas, and based on the relationship between characteristics of suppliers in a range of alternative screening to determine the appropriate business suppliers [5]. Ghodsypour for the selection of suitable suppliers to develop a decision support system (decision support system DSS), this system is mainly used to reduce the number of suppliers, mainly taking into account the ability of suppliers and buyers in the budget and limit costs by AHP method and mixed integer programming to make decisions, but also on the basis of qualitative and quantitative factors, changes in the right of each index value sensitivity analysis made [6]. Weber through the analysis of the selection of suppliers, he proposed the price, delivery, quality and capacity of the guidelines, in particular emphasis on the importance of JIT procurement in the transport distance and on time delivery [7].

\section{The Practical Application of Principal Component Analysis}

\subsection{The Basic Process of Principal Component Analysis Method}

The principal component method is applied to the reduction of dimension in the method of transforming several variables into a few synthetic variables. Each of the main components is a linear combination of the original variables. Each of the main components of the information does not overlap with each other, but can reflect the vast majority of information variables. The basic process of analysis is as follows.

- Standardized evaluation process: in indicators due to the selection of third-party 
suppliers, packaging, storage, transportation, handling and other indicators belong reverse indicators need to be translated into positive indicators, commonly used logarithmic or the reciprocal method for processing.

- Obtaining standardized data correlation matrix: A high degree of correlation between the various indicators, indicating indicators has great repeatability for the Principal Component Analysis.

- Find the eigenvalues of the correlation matrix, eigenvalue contribution rate, the cumulative contribution rate and weight to calculate the score of each index and the total score of the vendor evaluation.

\subsection{Evaluation Index Set}

Taking Liaoning Province as an example, After screening, there are four suppliers to choose from Now wants to conduct a comprehensive assessment of the four suppliers, Table 1 is a reflection of the four supplier index, a total of 18 indicators, 18 indicators which can be roughly divided into three categories, namely the financial situation, transportation and storage quality, comprehensive service index.

\subsection{The Basic Data Processing}

This paper mainly uses the SPSS21.0 statistical software to analyze the main components of the evaluation index. Because of the index of evaluation, we need to transform it into a positive indicator, and this paper mainly adopts the method of taking the reciprocal. And then the index is standardized (graph omission). Finally the total variance explained is shown in Table 2.

In SPSS output, there are three main components of eigenvalues greater than 1 , the three main components extracted from the initial solution, the cumulative variance contribution rate of $100 \%$, indicating that with these three main components representing the original 16 indicators comprehensive evaluation of logistics enterprises have sufficient grasp.

\subsection{Determine the Main Component and Score}

According to Table 3, the three principal component score formula is obtained by using the method of variance maximum.

$$
\begin{gathered}
Z_{1}=0.810 Z_{\text {SCORE }}\left(X_{1}\right)-0.761 Z_{\text {SCORE }}\left(X_{2}\right) \cdots-0.940 Z_{\text {SCORE }}\left(X_{18}\right) \\
Z_{2}=-0.531 Z_{\text {SCORE }}\left(X_{1}\right)-0.761 Z_{\text {SCORE }}\left(X_{2}\right) \cdots+0.350 Z_{\text {SCORE }}\left(X_{18}\right) \\
Z_{3}=0.248 Z_{\text {SCORE }}\left(X_{1}\right)-0.214 Z_{\text {SCORE }}\left(X_{2}\right) \cdots+0.910 Z_{\text {SCORE }}\left(X_{18}\right)
\end{gathered}
$$

In the first component, $Z_{\mathrm{SCORE}}(X 4), Z_{\mathrm{SCORE}}(X 5), Z_{\mathrm{SCORE}}(X 6)$ coefficient is larger. The first principal component is a comprehensive index of annual income, annual profit and cash flow, which reflects the financial situation of the supplier. The financial situation is an important index to evaluate the production and operation of an enterprise, which indirectly reflects the management level of the enterprise and the management strategy. It is reasonable to use the financial situation as the first principal component. 
Table 1. Supplier evaluation data.

\begin{tabular}{|c|c|c|c|}
\hline $\begin{array}{l}\text { Supplier } \\
\text { name }\end{array}$ & Transport (million) & Handling (million) & Package (million) \\
\hline 1 & 80 & 3 & 2.5 \\
\hline 2 & 100 & 4 & 3.5 \\
\hline 3 & 60 & 3.5 & 4 \\
\hline 4 & 105 & 2.5 & 3.2 \\
\hline $\begin{array}{l}\text { Supplier } \\
\text { name }\end{array}$ & Income (million) & Profit (million) & Cash flow (million) \\
\hline 1 & 300 & 2000 & 200 \\
\hline 2 & 1600 & 20000 & 600 \\
\hline 3 & 200 & 600 & 200 \\
\hline 4 & 2600 & 30000 & 700 \\
\hline $\begin{array}{l}\text { Supplier } \\
\text { name }\end{array}$ & Main business (million) & $\begin{array}{l}\text { Advertising expenditures } \\
\text { (million) }\end{array}$ & Outbound time rate (\%) \\
\hline 1 & 2 & 1 & 80 \\
\hline 2 & 1.8 & 0.8 & 60 \\
\hline 3 & 1.5 & 1 & 80 \\
\hline 4 & 2 & 0.5 & 100 \\
\hline $\begin{array}{l}\text { Supplier } \\
\text { name }\end{array}$ & Documents accuracy (\%) & $\begin{array}{c}\text { Transportation safety fac- } \\
\text { tor (\%) }\end{array}$ & $\begin{array}{c}\text { Transportation accuracy } \\
\text { rate }(\%)\end{array}$ \\
\hline 1 & 100 & 99 & 99 \\
\hline 2 & 99 & 98 & 98 \\
\hline 3 & 100 & 99 & 99 \\
\hline 4 & 99 & 100 & 100 \\
\hline $\begin{array}{l}\text { Supplier } \\
\text { name }\end{array}$ & Goods broken rate (\%) & $\begin{array}{l}\text { Quality of personnel } \\
\text { (10-point) }\end{array}$ & $\begin{array}{l}\text { Customer reviews } \\
\text { (10-point) }\end{array}$ \\
\hline 1 & 1 & 8 & 10 \\
\hline 2 & 0.1 & 6 & 8 \\
\hline 3 & 0.5 & 8 & 8 \\
\hline 4 & 2 & 8 & 6 \\
\hline $\begin{array}{l}\text { Supplier } \\
\text { name }\end{array}$ & $\begin{array}{l}\text { Transport records } \\
\text { (10-point) }\end{array}$ & $\begin{array}{l}\text { Storage security } \\
(10 \text {-point })\end{array}$ & $\begin{array}{l}\text { Storage timeliness } \\
\text { (10-point) }\end{array}$ \\
\hline 1 & 8 & 8 & 8 \\
\hline 2 & 10 & 9 & 10 \\
\hline 3 & 5 & 8 & 8 \\
\hline 4 & 8 & 6 & 4 \\
\hline
\end{tabular}

The second component is $Z_{\mathrm{SCORE}}(X 9), Z_{\mathrm{SCORE}}(X 13), Z_{\mathrm{SCORE}}(X 11)$ coefficient larger, the second principal component is by the library and timely rate, cargo damage rate and transportation safety rate characterizations of comprehensive index, which reflects the suppliers transport and storage quality. Transport and warehousing is an important part of is supply chain management, having certain transportation and storage capacity of the suppliers can not only ensure the successful completion of the transaction tasks but also can bring more customers for the enterprise, the position is second only to financial status. The last principal component is a comprehensive service index, which is 
Table 2. The total variance explained.

\begin{tabular}{|c|c|c|c|c|c|c|}
\hline \multirow{2}{*}{ Ingredient } & \multicolumn{3}{|c|}{ Initial eigenvalues } & \multicolumn{3}{|c|}{ Extracting square and load } \\
\hline & Total & Variance $\%$ & Accumulation \% & Total & Variance \% & Accumulation \% \\
\hline 1 & 9.624 & 53.465 & 53.465 & 9.624 & 53.465 & 53.465 \\
\hline 2 & 5.904 & 32.803 & 86.267 & 5.904 & 32.803 & 86.267 \\
\hline 3 & 2.472 & 13.733 & 100.000 & 2.472 & 13.733 & 100.000 \\
\hline 4 & $1.009 \mathrm{E}-013$ & $1.048 \mathrm{E}-013$ & 100.000 & & & \\
\hline 5 & $1.004 \mathrm{E}-013$ & $1.022 \mathrm{E}-013$ & 100.000 & & & \\
\hline 6 & $1.003 \mathrm{E}-013$ & $1.019 \mathrm{E}-013$ & 100.000 & & & \\
\hline 7 & $1.002 \mathrm{E}-013$ & $1.011 \mathrm{E}-013$ & 100.000 & & & \\
\hline 8 & $1.001 \mathrm{E}-013$ & $1.007 \mathrm{E}-013$ & 100.000 & & & \\
\hline 9 & $1.001 \mathrm{E}-013$ & $1.005 \mathrm{E}-013$ & 100.000 & & & \\
\hline 10 & $1.000 \mathrm{E}-013$ & $1.002 \mathrm{E}-013$ & 100.000 & & & \\
\hline 11 & $1.000 \mathrm{E}-013$ & $1.000 \mathrm{E}-013$ & 100.000 & & & \\
\hline 12 & $1.000 \mathrm{E}-013$ & $1.000 \mathrm{E}-013$ & 100.000 & & & \\
\hline 13 & $-1.001 \mathrm{E}-013$ & $-1.004 \mathrm{E}-013$ & 100.000 & & & \\
\hline 14 & $-1.001 \mathrm{E}-013$ & $-1.007 \mathrm{E}-013$ & 100.000 & & & \\
\hline 15 & $-1.002 \mathrm{E}-013$ & $-1.009 \mathrm{E}-013$ & 100.000 & & & \\
\hline 16 & $-1.003 \mathrm{E}-013$ & $-1.016 \mathrm{E}-013$ & 100.000 & & & \\
\hline 17 & $-1.003 \mathrm{E}-013$ & $-1.019 \mathrm{E}-013$ & 100.000 & & & \\
\hline 18 & $-1.005 \mathrm{E}-013$ & $-1.028 \mathrm{E}-013$ & 100.000 & & & \\
\hline
\end{tabular}

Extraction method: principal component analysis; extract three principal components.

Table 3. Composition matrix.

\begin{tabular}{cccc}
\hline & & Ingredient & \\
\hline & 1 & 2 & 3 \\
\hline$Z_{\text {SCORE }}\left(X_{\mathrm{I}}\right)$ & 0.810 & -0.531 & 0.248 \\
$Z_{\text {SCORE }}\left(X_{2}\right)$ & -0.671 & -0.710 & -0.214 \\
$Z_{\text {SCORE }}\left(X_{3}\right)$ & -0.231 & -0.189 & -0.954 \\
$Z_{\text {SCORE }}\left(X_{4}\right)$ & 0.929 & -0.344 & -0.137 \\
$Z_{\text {SCORE }}\left(X_{5}\right)$ & 0.901 & -0.413 & -0.129 \\
$Z_{\text {SCORE }}\left(X_{6}\right)$ & 0.832 & -0.531 & -0.160 \\
$Z_{\text {SCORE }}\left(X_{7}\right)$ & 0.648 & 0.004 & 0.761 \\
$Z_{\text {SCORE }}\left(X_{8}\right)$ & -0.969 & 0.170 & 0.178 \\
$Z_{\text {SCORE }}\left(X_{9}\right)$ & 0.648 & 0.955 & -0.102 \\
$Z_{\text {SCORE }}\left(X_{10}\right)$ & -0.741 & 0.656 & 0.146 \\
$Z_{\text {SCORE }}\left(X_{11}\right)$ & 0.648 & 0.855 & -0.102 \\
$Z_{\text {SCORE }}\left(X_{12}\right)$ & 0.648 & 0.755 & -0.102 \\
$Z_{\text {SCORE }}\left(X_{13}\right)$ & 0.813 & 0.870 & 0.118 \\
$Z_{\text {SCORE }}\left(X_{14}\right)$ & 0.102 & 0.695 & 0.501 \\
$Z_{\text {SCORE }}\left(X_{15}\right)$ & -0.759 & 0.077 & 0.646 \\
$Z_{\text {SCORE }}\left(X_{16}\right)$ & 0.367 & -0.769 & 0.523 \\
$Z_{\text {SCORE }}\left(X_{17}\right)$ & -0.930 & 0.357 & 0.091 \\
$Z_{\text {SCORE }}\left(X_{18}\right)$ & -0.940 & 0.350 & 0.091 \\
\hline S & & 1 &
\end{tabular}

Extraction method: principal component analysis; extract three principal components. 
composed of personnel quality, customer evaluation, and transport record. With good service ability is an important guarantee for enterprises to open up the market, as the third main components of supplier evaluation is an indispensable indicator.

According to Table 4, the first principal component is the main measure of the financial situation of each supplier. Score ranking are the supplier 4, supplier 2, supplier 1 , supplier 3 . In the second principal component, the transportation and storage quality advantages are supplier 3 , supplier 1, supplier 4, supplier 2. In the third principal component, the comprehensive service ability of the supplier 1 is superior to other suppliers. In the third principal component, the comprehensive service ability of the supplier 1 is superior to other suppliers. Enterprises can be based on each index score to pick out in a certain area has the advantage of suppliers for enterprise profit.

The first principal component is the main measure of the financial situation of each supplier. Score ranking are the supplier 4, supplier 2, supplier 1, supplier 3. In the second principal component, the transportation and storage quality advantages are supplier 3, supplier 1, supplier 4, supplier 2. In the third principal component, the comprehensive service ability of the supplier 1 is superior to other suppliers. In the third principal component, the comprehensive service ability of the supplier 1 is superior to other suppliers. Enterprises can be based on each index score to pick out in a certain area has the advantage of suppliers for enterprise profit.

The three main components of the variance contribution rate were 0.505, 0.34202, 0.19298. With three principal components variance contribution rate as weights, get each index of the comprehensive score in the above Table 5. Comprehensive score ranking are: the supplier 4, the supplier 1, the supplier 3, the supplier 2. According to the comprehensive score of each index, the enterprise can choose a comprehensive enterprise, which will be more conducive to enterprise production development and customer maintenance.

Table 4. The scores of each index.

\begin{tabular}{cccc}
\hline Supplier & $Z_{1}$ & $Z_{2}$ & $Z_{3}$ \\
\hline 1 & -3.80284 & 3.010255 & 3.54424522 \\
2 & -3.08909 & -7.669 & -0.57220002 \\
3 & -7.30337 & 3.08135712 & -2.35426568 \\
4 & 14.1953 & 1.57738807 & -0.61777823
\end{tabular}

Table 5. The total score of each index table.

\begin{tabular}{ccccc}
\hline Supplier & $Z_{1}$ & $Z_{2}$ & $Z_{3}$ & $Z$ \\
\hline 1 & -3.80284 & 3.0102 & 3.5442 & -0.559 \\
2 & -3.08909 & -7.669 & -0.5722 & -4.246 \\
3 & -7.30337 & 3.0813 & -2.3543 & -3.218 \\
4 & 14.1953 & 1.5774 & -0.6178 & 8.022 \\
\hline
\end{tabular}




\section{Summary}

The construction of index system is of practical significance for enterprises to choose their own suppliers. We should further improve the evaluation index system, especially in the weight of the determination of detailed analysis, so it constantly adapts to the changes of the times. For an enterprise, it is very important to establish a special organization to collect the information of the suppliers. Enterprises should establish their own supplier evaluation index system according to their own reality. Only the scientific evaluation index can be used to ensure that the results obtained when using these indicators are effective. As the supplier of the enterprise, it should comprehensively improve the comprehensive ability of the business to adapt to the external competitive environment.

\section{References}

[1] Guo, H.Y. (1998) Modern Statistical Methods and Applications. Renmin University of China Publishing House.

[2] Qian, B.B. (2000) Evaluation System of Partner Selection in Agile Virtual Enterprise. Chinese Mechanical Engineering, 11, 397-401.

[3] Ma, X.A. (2000) Supply Chain Partnership and Partner Selection. Industrial Engineering and Management, 4, 33-36.

[4] Moore and Fearon (2001) The Total Cost of Logistics in Supplier Selection. Production Economics, 75, 15-27.

[5] Johnson, M. (1998) An Analysis of the Supplier Selection Process. Omega, 26, 739-750. http://dx.doi.org/10.1016/S0305-0483(98)00023-1

[6] Ghodsypour, S.H. and O'Brien, C. (1998) A Decision Support System for Supplier Selection Using an Integrated Analytic Hierarchy Process and Linear Programming. International Journal of Production Economics, 56-57, 199-212. http://dx.doi.org/10.1016/S0925-5273(97)00009-1

[7] Weber, C.A., Current, J.R. and Benton, W.C. (1991) Vendor Selection Criteria and Methods. European Journal of Operational Research, 50, 2-18. http://dx.doi.org/10.1016/0377-2217(91)90033-R 
Submit or recommend next manuscript to SCIRP and we will provide best service for you:

Accepting pre-submission inquiries through Email, Facebook, LinkedIn, Twitter, etc. A wide selection of journals (inclusive of 9 subjects, more than 200 journals)

Providing 24-hour high-quality service

User-friendly online submission system

Fair and swift peer-review system

Efficient typesetting and proofreading procedure

Display of the result of downloads and visits, as well as the number of cited articles

Maximum dissemination of your research work

Submit your manuscript at: http://papersubmission.scirp.org/

Or contact jssm@scirp.org 